\title{
Molecular Recognition of Neutral Substrates by New Tetraaminocalix[4]arene Derivative
}

\author{
Satish Balasaheb Nimse, Keum-Soo Song, Chan-Yong Jung, ${ }^{\dagger}$ Woon-Yong Eoum, ${ }^{\dagger}$ and Taisun Kim \\ Institute for Applied Chemistrv and Deparment of Chemistry. Hallw Chiversity, Chuncheon 200-702, Korea \\ E-mail: tskimahallymackr \\ ${ }^{\dagger}$ Biometrix Technologw, Inc., 202 Biol'enture Plaza. Chumcheon 200-161. Korea \\ Received Aarch 19, 2009, Accepted.April 28, 2009
}

\begin{abstract}
The recognition of neutral aromatic substrates by different neutral calix [4]arene receptors 1, 2 , and $\mathbf{3}$ was studied by NMR spectroscopy. The stoichiometry is $1: 1$ in all cases as was confimed by jobs plot. Owing to the deep cavity, 1 affords stronger binding abilities for substrate 4 and 5 , while all receptors remained inert for substrates 6 and 7 . The binding constants deternined by ${ }^{1} \mathrm{H} N \mathrm{MR}$ titration show that the recognition of substrate $\boldsymbol{\dagger}$ by $\mathbf{1}$ gives strongest complexation $\left(K_{a}\right.$ of $\left.9.8 \times 10^{2} \mathrm{M}^{-1}\right)$
\end{abstract}

Key Words: Tetraaminocalixarene. Molecular recognition. Neutral substrates. Deep cavity

\section{Introduction}

Calixarenes are versatile bowl-shaped platform's which can be functionalized to provide a range of interesting molecular architectures with well defined special arrangement of the substituents. ${ }^{123}$ The easily tunable shape of the molecules. together with almost unlimited possibilities of chemical transformations, make calixarenes a more sophisticated molecular system. Derivatives of the calix[4]arene and tert-butylcalix$[4]$ arene shown in Scheme 1 have been widely used as molecular receptors ${ }^{4.5}$ and as the scaffold for the design and synthesis of wide range of receptors with recognition ability towards both neutral and charged molecules. ${ }^{6.8}$

The development of upper and lower rim modified receptors has been tremendously exploited. which has resulted in to several derivatives such as ethers. aldehydes. imines. esters. amides. ${ }^{9}$ These types of derivatives were targeted to recognize charged and neutral molecular species in aprotic solvents. ${ }^{\text {li.11 }}$ A large volume of research data is available on recognition of ionic substrates ${ }^{13}$ but very few is available on recognition of neutral guests due to the limitations of forces involved in the molecular recognition process: as a consequence. the inclusion properties of neutral guests by neutral calixarene derivatives is considered to be stringent. ${ }^{[3,14}$ The neutral abiotic receptor for neutral substrates of biochemical. medical and environmental importance is an area of intense research activity obligating the development of the neutral molecular receptor. $^{1 ?}$

It was hypothesized that the phenolic oligomers represented by calix[4]arenes could in principle provide excellent platforms for the construction of attractive recognition sites for host-guest interaction. ${ }^{16.17}$ It is assumed that the new molecular receptors with deep cavities may enhance the recognition process of the aromatic guest in aprotic organic solvent. The tetraaminocalix[4]arene derivative 1 can be easily prepared

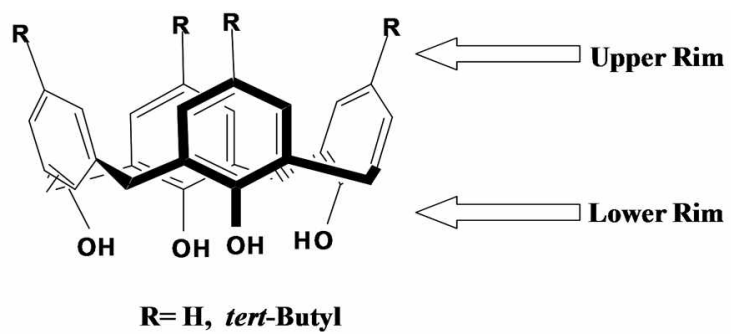

Scheme 1

by introducing tetraamino functional groups on the upper rim of calix[4]arene. In this paper. the recognition of aromatic guests by 1 was studied and the results were compared with those of $\mathbf{2}$ and $\mathbf{3}$.

\section{Result and Discussion}

The required starting materials tert-butylcalix[4]arene and calix[4]arene were synthesized following literature procedures. The dialkylation of these compounds was achieved by refluxing with l-bromopropane in the presence of $\mathrm{K}_{2} \mathrm{CO}_{3}$ in anhydrous $\mathrm{CH}_{3} \mathrm{CN}$ under nitrogen atmosphere to obtain receptor 2 and 3. ${ }^{19}$ As shown in Schente 2, receptor 1 was obtained by slightly modified nitration ${ }^{20}$ of calix[4]arene followed by well known reduction ${ }^{21}$ to produce tetraaninecalix[4]arene. Tetraaminecalix[4]arene on selective $N$-alkylation ${ }^{-2}$ with benzyl bromide in the presence of a base resulted in tetradibenzy laminocalix[4]arene. which was dialkylated at the lower rim with a similar procedure as employed for receptor 2 and 3 . A detailed synthesis of receptor 1 will be reported elsewhere.

All of the receptors shown in Scheme 3 were characterized by analysis of their ${ }^{1} \mathrm{H} N M R$ and ${ }^{13} \mathrm{C}$ NMR spectra. For example, the ${ }^{1} \mathrm{H}$ NMR spectrum of 1 showed a typical $\mathrm{AB}$ pattern represented by two pairs of doublets at $\delta 3.00$ and $\delta$ 

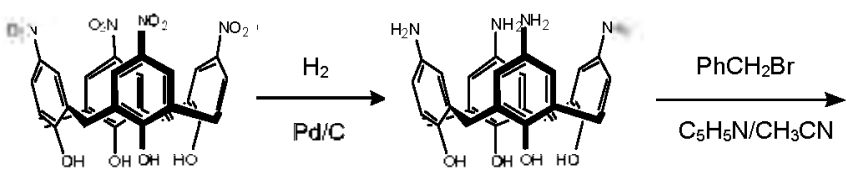
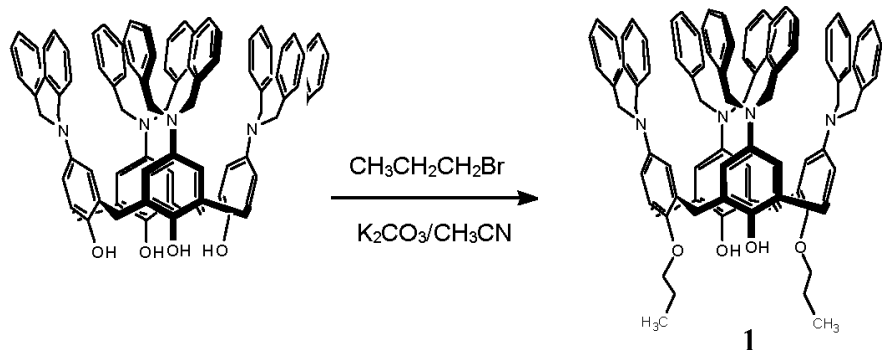

Scheme 2. Synthesis of receptor 1

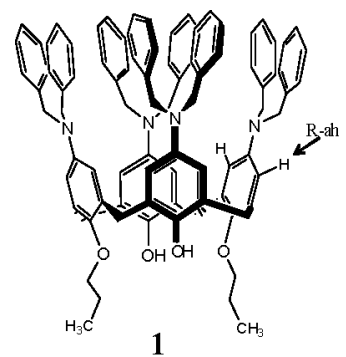

1

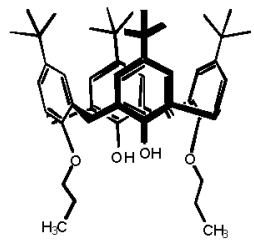

2

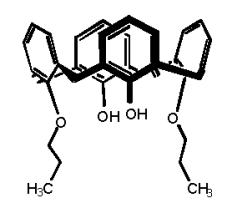

3

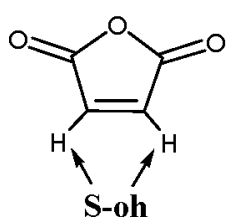

4<smiles>c1c[nH]cn1</smiles><smiles>COc1ccccc1</smiles>

6<smiles>CN(C)c1ccccc1</smiles>

7

Scheme 3

4.20 for the axial and equatorial protons, respectively. which indicated that 1 existed in a symmetrical cone conformation. This was further confirmed by the observation of a distinct signal at 532.82 for the methylene carbon in the ${ }^{13} \mathrm{C} N \mathrm{NM}$ spectnim. $^{2 ?}$

The receptors 1,2 . and 3 were examined for their interaction with various substrates such as maleic anhydride 4 . immidazole 5 , anisole 6 and $N . N$-dimethy laniline 7 as shown in Scheme 4.

The recognition characteristics of all receptors were investigated in detail by ${ }^{\mathrm{H}} \mathrm{H}$ NMR experiments in deuterated clloroform. which revealed significant chemical induced upfield shifts (CIUS) for proton resonances in the selective substrates. while minimal or no changes were observed for the receptors themselves in the tested concentration range. The substrate protons were observed as averaged single resonances because of the fast exchange on the NMR timescale between the free and complexed substrate.

The ${ }^{\mathrm{H}} \mathrm{H}$ NMR titration experiments conducted in $\mathrm{CDCl}_{3}$

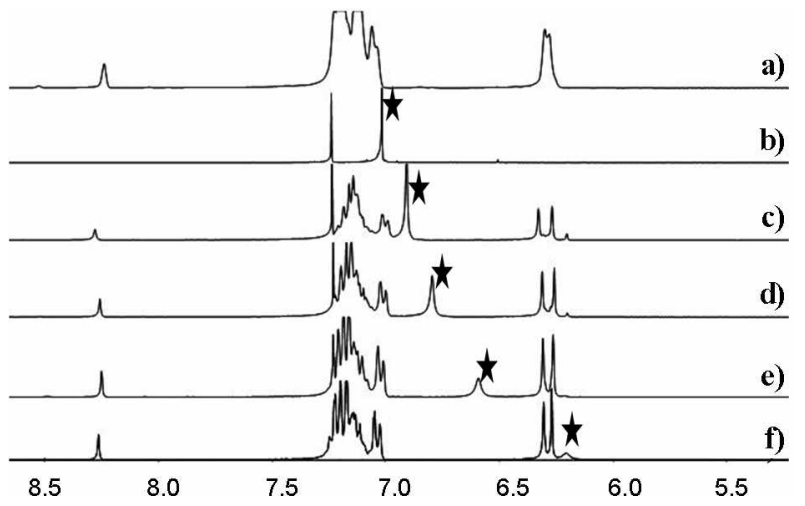

Figure 1. Partial ${ }^{1} \mathrm{H} \mathrm{NMR}\left(\mathrm{CDCl}_{3}\right.$ at $298 \mathrm{~K}$ ) spectra of substrate 4 upon titration with receptor 1 . a) receptor 1 , b) substrate 4 , c) $4+$ 0.125 equiv of 1, d) $4+0.25$ equiv of 1, e) $4+0.5$ equiv of $1, f) 4+$ 1.0 equiv of 1 . indicated that the $\mathrm{CH}=\mathrm{CH}$ signal at $\delta 7.20$ for substrate 4 and $\mathrm{CH}=\mathrm{CH}$ signal at $\mathrm{o} 7.13$ for substrate 5 were markedly affected by the addition of receptors 1.2 , and 3. while no effects on chemical shifts were observed for the aromatic as well as alkyl signals of substrates 6 and 7 . Figure 1 illustrates that the maximum upfield shift of $0.83 \mathrm{ppm}$ was observed for the $\mathrm{CH}=\mathrm{CH}$ protons of Substrate 4 upon the addition of 1.0 equivalent of receptor 1. while marked upfield shifts of $0.44 \mathrm{ppnt}$ were also observed upon titration with receptors 2 and 3 respectively. as shown in Figure 2 and Figure 3.

The substrate concentration was kept constant $\left(1 \times 10^{\circ} \mathrm{M}\right)$ while the receptor concentration was varied from $0.125 \times 10^{-2}$ to $1 \times 10^{-2} \mathrm{M}$ and the chentical shifts of the $\mathrm{CH}=\mathrm{CH}$ protons were recorded at each concentration. The obtained ${ }^{1} \mathrm{H}$ NMR data was analyzed by the well known Rose-Drago method ${ }^{\text {-4 }}$ which allowed the calculation of association constant $\left(K_{0}\right)$. The values obtained are presented in Table 1. Receptor 1 showed maximum $K_{4}$ of $9.8 \times 10^{2} \mathrm{M}^{3}$ with 4 and $6.1 \times 10^{2} \mathrm{M}^{3}$ with 5 , while receptor 2 shows $K_{a}$ of $5.71 \times 10^{-} \mathrm{M}^{-1}$ with 4 and

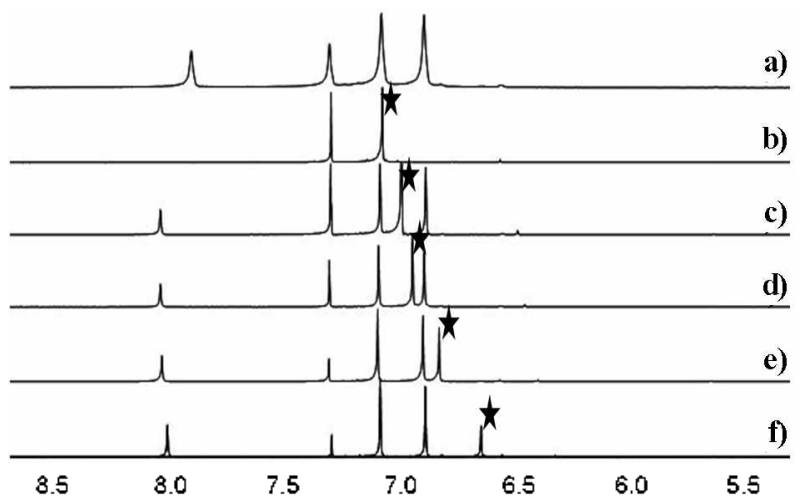

Figure 2. Partial 'H NMR (CDCl 3 at $298 \mathrm{~K}$ ) spectra of substrate 4 upon titration with receptor 2 a) receptor 2 , b) substrate 4 , c) $4+$ 0.125 equiv of 2, d) $4+0.25$ equiv of 2 , e) $4+0.5$ equiv of $2, f) 4+$ 1.0 equiv of 2 . 


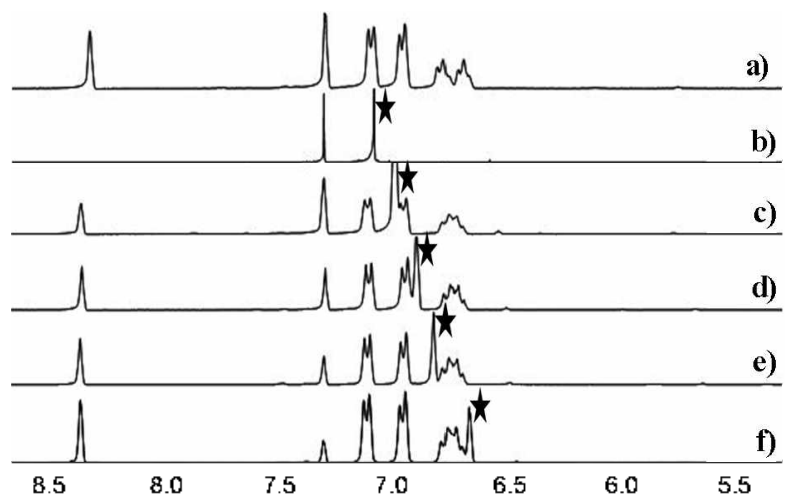

Figure 3. Partial ${ }^{1} \mathrm{H}$ NMR (CDCl 3 at $298 \mathrm{~K}$ ) spectra of substrate 4 upon titration with receptor 3 a) receptor 3 , b) substrate 4, c) $4+$ 0.125 equiv of 3, d) $4+(0.25$ equiv of 3, e) $4+0.5$ equiv of $3, t) 4+$ 1.0 equiv of 3

(a)

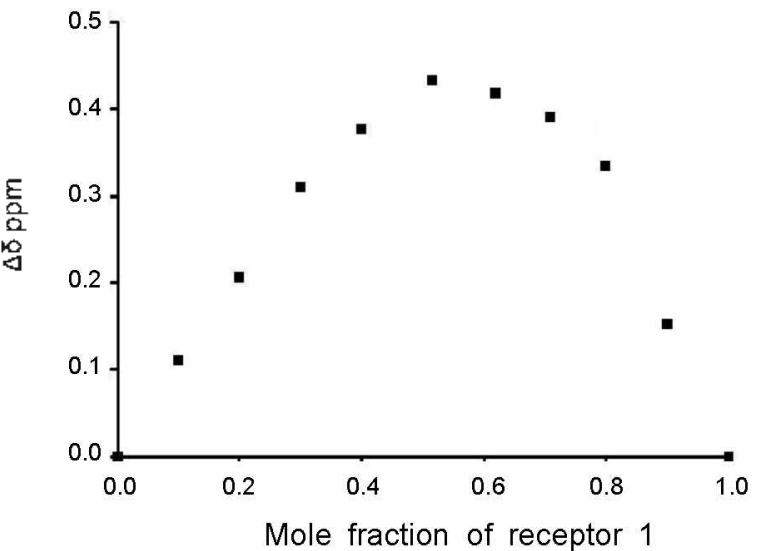

(b)

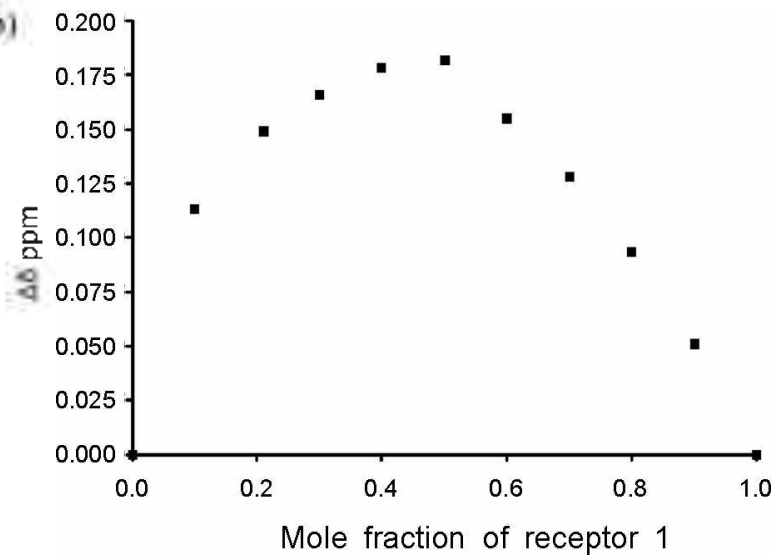

Figure + . Job 's Plot for the titration of 'Teceptor 1 with aj substrate 4 , b) substrate 5 in CDCl $]_{3}$ at $298 \mathrm{~K}$.

$4.01 \times 10^{2} \mathrm{M}^{1}$ with 5 , receptor 3 shows $K_{a}$ values of $5.49 \times 10^{2}$ $\mathrm{M}^{-1}$ and $3,81 \times 10^{2} \mathrm{M}^{-1}$ with 4 and 5 respectively. While substrates 6 and 7 remained unbound. As shown in Figure 5. substrate 4 shows maximum CIUS of $0.83 \mathrm{ppm}$ with receptor 1 comparcd 102 and 3.

Based on the NMR titration data. binding-stoichiometries of the above complexes were confirmed to be $1: 1$ by Job s plot method ${ }^{25}$ with maximum complexation at $0.5 \mathrm{~mol}$ fraction of substrates 4 and 5 wilh receptor 1 as shown in Figure 4 .

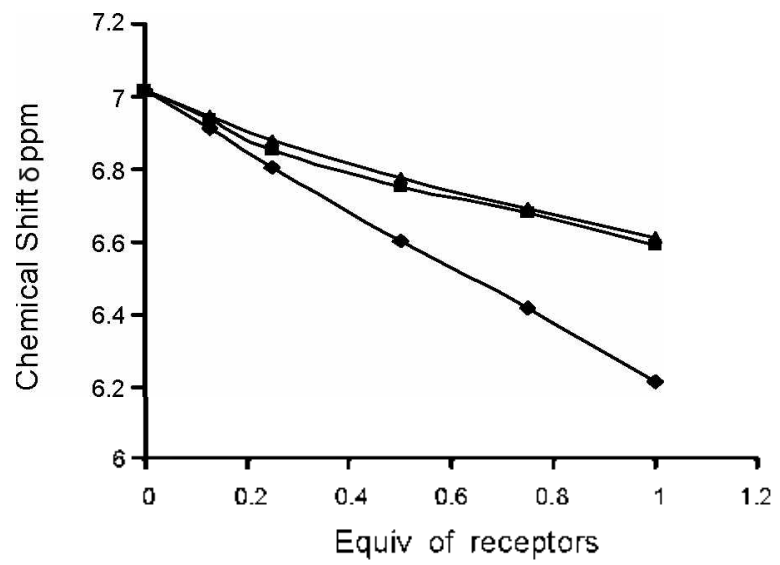

Figure 5. 'II NMR titration curves of ClI=CH proton of 4 upon titration with receptor $-1, \mathbf{n - 2}$ and $\boldsymbol{\Delta}-3$. (a)

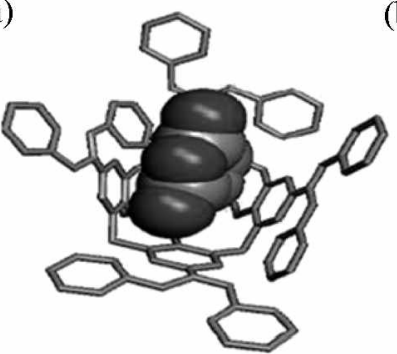

(b)

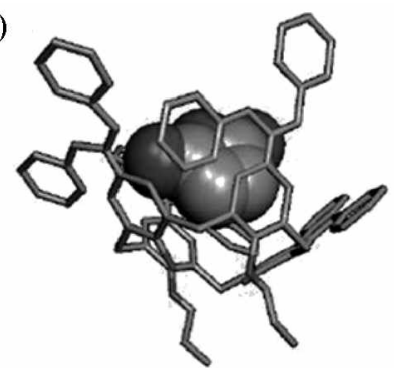

Figure 6. Fnergy minimized structure of complex between receptor 1 and substrate + by Spartan $(M M+$ Force licield, the hydrogen s were removal for clarity]. a) lop vicw; b) Sidle view.

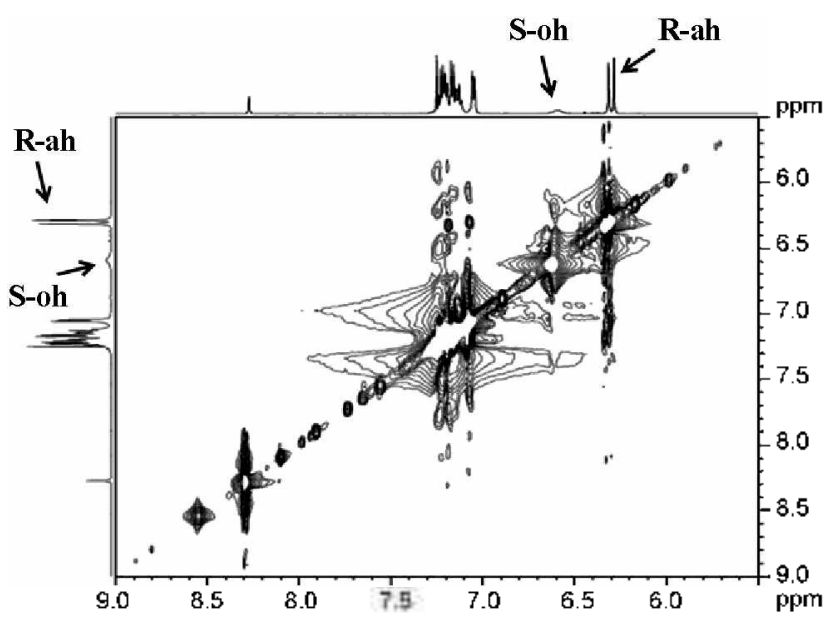

Figure 7. Partial 2L) NOLiSY spectrum (Bruker $600 \mathrm{Ml}$ L NMR) of complex between receptor 1 and substrate 4 . I he abbreviations $R$-ah and S-oh stands for aromatic protons of calix|+farene and oletinic protons of substrate, respectively:

The results in Table 1 demonstrate that all of the receptors showed similar pattern of recognition towards substrates + and 5 . in fact substrate 4 is better accommodated in the cavity of receptor 1 than substrate 5. From Figure 5, the increasing order of affinity of the receptors for substrate $\downarrow$ can be presented as $\mathbf{3}<\mathbf{2}<\mathbf{1}$. The similar order of affinity is also found 
Table 1. Chemical shift values ( $\Delta \delta \mathrm{ppm}$ ) and association constants $\left(K_{\sigma} \mathrm{M}^{-1}\right)$ of substrates upon addition of receptors, in CDCl $:(300)$ $\mathrm{MHz}$ and $298 \mathrm{~K}$ )

\begin{tabular}{|c|c|c|c|c|}
\hline \multirow{2}{*}{ Receptor } & \multicolumn{4}{|c|}{ Guest $\Delta \delta \mathrm{ppm}\left(K_{a} \mathrm{M}^{-1}\right)$} \\
\hline & 4 & 5 & 6 & 7 \\
\hline 1 & $0.83\left(9.78 \times 10^{2}\right)$ & $0.45\left(6.11 \times 10^{2}\right)$ & "n1s & $11 \mathrm{~s}$ \\
\hline 2 & $0.44\left(5.71 \times 10^{2}\right)$ & $0.36\left(4.01 \times 10^{2}\right)$ & $n 1 \mathrm{~s}$ & $11 \mathrm{~s}$ \\
\hline 3 & $0.44\left(5.49 \times 10^{\circ}\right)$ & $0.33(3.81 \times 10 \hat{9})$ & $n 1 \mathrm{~s}$ & $11 \mathrm{~s}$ \\
\hline
\end{tabular}

"ns indicates no change in chemical shift.

in case of substrate 5 . Substrate 4 as well as 5 show significant association constants with receptor 1 as compared with receptors 2 and 3 .

The energy minimized structure generated by Spartan ${ }^{\text {e }}$ (MM+Force Field) for a complex between receptor 1 and substrate 4 was shown in Figure 6. As shown in Figure 7. the special arrangement of substrate $\mathbf{4}$ in receptor 1 was confirmed by NOESY measurements (600 MHz. $\mathrm{CDCl}_{3}, 298 \mathrm{~K}$ ). The partial 2D NOESY spectrum of complex between receptor 1 and substrate 4 (the labeled protons shown in Scheme 3 and 4) shows that correlation exists between the broad peak of S-oh protons at $\delta 6.60$ of substrate 4 and the peak of R-ah protons at $\delta 6.30$ of receptor 1 . The high binding affinity of substrates 4 and 5 towards receptor 1 is attributed to its deep cavity generated by tetradibenzylamino groups on the upper rim of calix[4]arene.

\section{Conclusion}

These experiments demonstrate the utility of uncomplicated synthetic supramolecular model systems for probing experimentally the fundamental nature of weak noncovalent interactions in biological systems. Here. we have shown that calix[4]arenes with deep cavities may exhibit high affinity for small and neutral substrates. Based on the results generated by our experiments. we are working on the development of water-soluble aminocalixarenes for the effective recognition of pathologically important biomolecules.

Acknowledgments. This Study was supported by Technology Development Program for Agriculture and Forestry. Ministry for Agriculture. Forestry and Fisheries. Republic of Korea.

\section{References}

1. Gutsche, C. D. In Calixarenes Revisited; Roval Society of Chemistry: Cambridge, 1998; p 50.

2. Ikeda, A.: Shinkai, S. Chem Rev. 1997, 97, 1713.

3. Boluner, V. Angew. Chent. Int. Ed Engt. 1995, 34, 713 .

4. (a) Vicens, J.; Bohmer, V. In Calixarenes: A Jersatile Class of Macrocyclic Componds; Kluwer: Dordrecht, 1991; p 127. (b) Lhotak, P.: Zieba, R.: Hromadka, V.; Stibor, I.: Sykora, I. Tetrahedron Lett. $2003,44,4519$.

5. (a) Oh, S. W.; Moon, T. D.; Lim, H. J.; Park, S. Y.; Kim, T.; Park, I. Han, M. H.; Snyder, M ; Choi, E. Y.; J. Fed A. Soc. Exp. Biol. 2005, 19, 1335. (b) Jung, H.; Song, K.; Kinn, T. Bull Korean Chem. Soc. 2007, 28, 1792. (c) Demody, D. L.; Crooks, M. R.: Kim. T. J. An. Chem. Soc 1996, H18, 11912. (d) Demody, D.
L.: Lee, Y.; Kim, T.: Crooks, R. M. Langmin 1999, 15, 8435, (e) Lee, Y.: Lee, E. K.; Cho, Y. W.: Matsui, T.; Kang, I.: Kim, T.; Han, M. H. Proteomics 2003, 3. 2289.

6. (a) Andreetti, G. D; Ungaro, R.; Pochini, A. J. Chem. Soc. Chem. Comm 1979, 1005. (b) Nachtigall, F. F.; Lazzarotto, M:; Nome, F. J. Braz. Chem. Soc. 2002, 13, 295

7. (a) Yilmaz. A: Memon. S.: Yilmaz. M. Tetrahedron 2002. 58 . 7735. (b) Chawla, H. M.; Singh, S. P. Tetwhedron 2008, 64, 741. (c) Sdira, S. B.; Felix, C.; Giudicelli, M.; Vocanson, F: Perrin, M.; Lamartine, R. Tenahedron Letters 2005, $\$ 6,5659$.

8. (a) Yang, F.: Ti, Y.; Guo, H.: Lin, J.: Peng, Q. Sin. Comm, 2007, 37, 79. (b) Baklouti, L.; Cherif, J.; Abidi, R.; Amaud-Neu, F.; Harrowfield, J.; Vicens, J. Org. Biontol. Chen 2004, 2, 2786.

9. (a) Kang, S. O.; Nam, K. C. Bull Korean Chem. Soc. 2002, 23 . 640. (b) Baldini, L.: Sansone, F.; Casnati, A.; Ugozzoli, F.: Ungaro, R. J. Supra. Chem. 2002. 2.219. (c) Mivaji, H.: Dudic, M.; Tucker, J. H. R.; Prokes, I.; Light, M. E.; Hursthouse, M. B.; Stibor, I.; Lhotak, P. Tetrahedron Lett. 2002, 43, 873. (d) Kumar, S.: Chawla, H. M: Varadarajan. R. Tetrahedron Lett. $2002,+3,2495$.

10. (a) Gartier, E.; Le Gac, S. L.: Jabin, I. Tetrahedron: Armmeny 2005, 16, 3767. (b) Chawla, H. M.; Sahu, S. M.; Shrivastava, R. Tetritedron Letters $\mathbf{2 0 0 7}, 48,6054$.

11. (a) Kocabas, E.: Durmaz, M.; Alpaydin, S.: Sirit, A.: Yilmaz, M. Chiralit 2008, 20, 26. (b) Korbakov, N.: Timmenman. P.: Lidich. N.: Urbach, B.; Saar, A.; Yitzchaik, S. Lamgnthir 2008, 24, 2580.

12. (a) Schmidtchen, F. P.; Berger, M. Chem. Rev. 1997, 97, 1609 (b) Beer, P. D.; Gale, P. A. Angew. Chemt. Int. Ed. 2001, 40, 486. (c) Masci. B.: Persiani. D.: Thuer, P. J Ong Chem 2006.71.9784.

13. Lehn, J.: Vogle, F.: MacNicol, D. D.: Davis, I. E.: Atwood, J. L. In Comprehensive Supromalecular Chentistry, Pergamon: UK, 1996: p 69

14. Arduini, A.: Brindani, E:; Giorgi, G.: Pochini, A: Secchi, A. Tetrahendron 2003, 59,7587.

15. (a) Chawla, H. M.; Pant, N.; Srivastaya, B.; Upreti, S. Org. Lett. 2006, 8, 2237. (b) Chawla, H. M.; Singh, S. P.; Sahu, S. N.; Upreti, S. Tetrahedron 2006, 62, 7854.

16. (a) Valeur, B.: Leray, I. Horg Chim .Acta 2007, 360, 765. (b) Petrella, A. I. Raston. C. L. J. Organontet Chent. 2004, 689 . 4125. (c) Valeur, B.; Leray, I. Coord. Chemt Rev, 2000, 205, 3.

17. Baldini, L.; Casnati, A.; Sansone, F.; Ungaro, R. Chem. Soc. Rev. 2007, 36, 254.

18. Iqbal. M:- Mangiatico, T.: Gutsche. C. D. Tetrahedron 1987, $43,4917$.

19. (a) Casnati, A.; Pochini, A.; Ungaro, R.; Ugozzoli, F.; Arnaud, F.; Fanni, S.; Schwing, M.; Ehberink, R. J. M.; Jong, F.; Reinhoudt. D. N. J. Am. Chem. Soc. 1995, 117,2767. (b) Receptor2: ${ }^{1} \mathrm{H} \mathrm{NMR}\left(300 \mathrm{MHz}, \mathrm{CDCl}_{3}\right): \delta 1.01\left(\mathrm{~s}, 18 \mathrm{H},-\mathrm{C}\left(\mathrm{CH}_{3}\right)\right), 1.26$ (s, $\left.18 \mathrm{H},-\mathrm{C}\left(\mathrm{CH}_{3}\right)_{3}\right), 1.32\left(\mathrm{t}, 6 \mathrm{H}_{3}-\mathrm{CH}_{3}\right), 1.99(\mathrm{q}, 4 \mathrm{H}, J=7.148$, $\left.-\mathrm{CH}_{2}-\right), 3.32\left(\mathrm{~d}, 4 \mathrm{H}, J=12.65 \mathrm{~Hz}, \mathrm{Ar}-\mathrm{CH}_{2}-\mathrm{Ar}\right), 3.9 \mathrm{l}(\mathrm{q}, 4 \mathrm{H}, J=$ $6.60 \mathrm{~Hz},-\mathrm{OCH} 2), 4.26\left(\mathrm{~d}, 4 \mathrm{H}, J=12.647 \mathrm{~Hz}, \mathrm{Ar}-\mathrm{CH}_{2}-\mathrm{Ar}\right), 6.85$ (s. 4H. Ar-H). 7.01 (s. 4H. AI-H). 7.95 (s. 2H. AI-OH). (c) Receptor 3: ${ }^{1} \mathrm{H} N M R\left(300 \mathrm{MHz}, \mathrm{CDCl}_{3}\right): \delta 1.28(\mathrm{t}, 6 \mathrm{H}, J=7.69$ $\left.\mathrm{Hz},-\mathrm{CH}_{3}\right), 2.05\left(\mathrm{q}, 4 \mathrm{H}, J=13.19 \mathrm{~Hz},-\mathrm{CH}_{2}-\right), 3.34(\mathrm{~d}, 4 \mathrm{H}, \mathrm{J}=$ 12.64 Hz, Ar-CHz-Ar), $3.96\left(\mathrm{t}, 4 \mathrm{H}, J=4.94 \mathrm{~Hz},-\mathrm{OCH}_{2}\right) 4.28(\mathrm{~d}$, $\left.4 \mathrm{H}, J=12.64 \mathrm{~Hz}, \mathrm{Ar}-\mathrm{CH}_{2}-\mathrm{Ar}\right), 6.60(\mathrm{t}, 2 \mathrm{H}, J=7.14 \mathrm{~Hz}, \mathrm{Ar}-\mathrm{H})$, $6.71($ t. $2 \mathrm{H} . J=6.59 \mathrm{~Hz} . \mathrm{Ar}-\mathrm{H}) .6 .88$ (d. $2 \mathrm{H} . J=7.14 \mathrm{ArH}) .7 .(12$ (d, $2 \mathrm{H}, J=7.14 \mathrm{Ar}-\mathrm{H}), 8.28(\mathrm{~s}, 2 \mathrm{H}, \mathrm{Ar}-\mathrm{OH})$.

20. (a) Shinkai, S.; Tsubaki, T.; Sone, T.; Manabe, O. Tetrahedron Letters 1985, 26, 3343. (b) Zhang, W.; Zheng, Y.; Huang, Z. Sunth. Commm 1997, 27, 3763. (c) Kumar. S.: Kurur. N. D.: Chawla, H. M: Varadarajan, R. Sinth. Commun. 2001, 31, 775 .

21. (a) Wageningen, A. M. A.; Snip, E.; Verboom. W.; Reinhoudt, D. N.: Boerrigter, H. Liebigs .4m Recueil 1997, 2235

22. Funis, B. S.: Hannaford, A. J.: Smith, P. W. G.; Tatchell A. R. In Fogel's Text Book of Practical Organic Chemistny, Longmann: England, 1989; 9962

23. Receptor 1: ${ }^{1} \mathrm{H} N \mathrm{MR}(300 \mathrm{MHz}, \mathrm{CDCl} 3$ ) 81.23 (t, $6 \mathrm{H}, J=7.14$ $\left.\mathrm{Hz},-\mathrm{CH}^{\prime}\right), 2.02\left(\mathrm{q}, 4 \mathrm{H}, J=13.74 \mathrm{~Hz},-\mathrm{CH}_{2}-3\right), 300(\mathrm{~d}, 4 \mathrm{H}, J=$ $\left.12.10 \mathrm{~Hz}, \mathrm{Ar}-\mathrm{CH}_{2}-\mathrm{Ar}\right), 3.82\left(\mathrm{q}, 4 \mathrm{H}, J=6.10 \mathrm{~Hz},-\mathrm{OCH}_{2}\right), 4.19$ (d, $\left.4 \mathrm{H}, J=12.65 \mathrm{~Hz}, \mathrm{Ar}-\mathrm{CH}_{2}-\mathrm{Ar}\right), 4.25\left(\mathrm{~s}, 8 \mathrm{H},-\mathrm{N}-\mathrm{CH}_{1}-\mathrm{Ar}\right), 4.27$ 
$\left(\mathrm{s}, 8 \mathrm{H},-\mathrm{N}-\mathrm{CH}_{2}-\mathrm{Ar}\right), 6.27(\mathrm{~s}, 4 \mathrm{H}, \mathrm{Ar}-\mathrm{H}), 6.30$ (s, 4H, Ar-H), 7.05$7.24(\mathrm{~mm}, 40 \mathrm{H}, \mathrm{Ar}-\mathrm{H}), 8.82(\mathrm{~s}, 2 \mathrm{H}, \mathrm{Ar}-\mathrm{OH}){ }^{13} \mathrm{C} \mathrm{NMR}\left(\mathrm{CDCl}_{3}\right): 8$ $11.38,23.72,32.89,54.76,78.53,113.59,126.72,126.89$, $127.32,128.56,129.09,134.50,138.99,139.60,142.89,144.19$, $145.29,146.79$. MALDI-TOF MS $n: z(\mathrm{M}+): 1288.7$

24. (a) Shalley, A. C. In . Analytical Methots in Supramolecular Chemistn: WILEY-VCH Verlag GmbH \& Co. KGaA: Weinheim, 2007; p 39. (b) Rose, N. J. Drago, R. S. J. Am. Chem. Soc.
$1959,81,6138$.

25. (a) Job's plot: Solution of the receptor $1(10 \mathrm{mM})$, substrate 4 $(10 \mathrm{mM})$ and $5(10 \mathrm{mM})$ in $\mathrm{CDCl}_{3}$ were separately prepared. The ${ }^{1} \mathrm{H}$ NMR tubes were filled with $500 \mu \mathrm{L}$ solution of the receptor and the substrate in the following volume ratios (all in $\mu \mathrm{L}$ ): $50: 450,100: 400,150: 350,200: 300,250: 250,300,200,350: 150$, 400:100, 450:50 (b) Scheerder. J.: Fochi, M.: Engbersen. I. F. J.; Reirhoudt, D. N. J. Org. Chent 1994, $59,7815$. 